\title{
The Influence of Human Resources and Job Opportunity on Economic Growth in North Sumatera Province
}

\author{
Kurnia Novianty Putri \\ Department of Economy \\ Post Graduate School, State University Of Medan \\ Medan, North Sumatera, Indonesia \\ email: kurnianovianty@ymail.com
}

\author{
Fitrawaty, Sri Fajar Ayu \\ Post Graduate School, State University Of Medan \\ Medan, North Sumatera, Indonesia
}

\begin{abstract}
The formulation of the problem in this research is whether there is influence of human resources and job opportunities to economic growth in North Sumatera. This study uses secondary data where the human resource was measured through components is; Welfare, education, productive age, and environmental support, while the job was derived from two components namely; Population and labor force. All data including the economic growth of North Sumatra Province is obtained from Central Bureau of Statistics in North Sumatra. This research uses multiple linear regression technique with time series data. Before doing the technique of inferential statistic first done classical assumption test, covering; Normality test, linearity test, heteroskedasticity test, autocorrelation test, and multicollinearity test. The result of this research is the influence of human resources and job opportunity to economic growth in North Sumatera Province.
\end{abstract}

Keywords - human resources; job opportunities; economic growth

\section{INTRODUCTION}

The economy of a country indicates a condition of the state public power in a variety of small and large transaction as an effort to satisfying human needs. Economic growth can be interpreted as a process of changing economic conditions of a region from a certain period. The expected economic growth is the better one. Good economic growth reflects the improvement of civilization, welfare, and happiness of community in the region. Currently all countries in the world compete against the increase of its economy. The economic growth of a country reflects the power of the country in the world.

Jhingan (2004) said that modern economic growth can be interpreted as a sharp increase in per capita products and in population. Sadono (1995) said that economic growth contains two different meanings. Common use, economic growth is defined as the growth of national income that occurs in a country from year to year based on the increase in population. According to the Central Bureau of Statistics (Badan Pusat Statistik), the level of economic growth of a region can be seen through Gross Regional Domestic Product (Produk Domestik Regional Bruto).

One of the factors of economic growth is the effective human resources. Human resources have an important role in economic growth because human resources have the ability to think, develop, and work to produce goods and services in the economy. Sudarman (1986) said that human resources are the factors of production encompassing all human endeavors both physical and mind shown to produce goods and services. Human resources can be seen from the aspect of quality is the ability of work in the process of production of goods and services, it can also be seen in the quantity aspect that is the number of people who are able to work. Human resources is any resident who has the potential to conduct productive activities for themselves and the community in accordance with the knowledge and skills possessed. Humans have the potential to be developed in accordance with the knowledge and skills possessed to be qualified human beings.

Human development affects economic growth because effective and sustainable human development can achieve better economic growth. Meanwhile, economic growth affects human development through increased productivity and job creation. There is a reciprocal correlation between economic growth and human resource development. However, this correlation does not automatically occur empirically. There are regions (provinces) in Indonesia that experience rapid economic growth without being followed by balanced human development. Raharjo (2008) mentioned that human resources are the main basis for the welfare of each country. Efforts to improve the quality of human resources are implemented in various sectors, among others, the education sector, health, and the productive age population. The concept of human development in development policies simply does not mean abandoning past developments such as accelerating economic growth and reducing poverty. It is clear that human resources affect economic growth in a country as well as at the provincial level. Global Human Development Report (HDR) has developed and measured human development in the form of Human Development Index (HDI). 
Expansion of job opportunities necessary to be done to improve the productivity of human resources. With widespread job means more workers can work and earn more. And this also affects the increasing number of people who have increased the welfare of his life. According Soeroto (1986) that job opportunities and the number and quality of people used in the work has a decisive function in development. This is not only because the workforce is the implementer of development, but also because they work or work is the main source for community.

Sunindhia (1988) said that the expansion of job opportunities can only be accomplished by extending the basis of economic activity, but this broadening of economic base must be accompanied by efforts to increase productivity both in the field of new and traditional activities. This is because one of the factors that generally inhibits production in developing countries is low productivity coupled with a lack of full use of the labor force. From the statement above can be said that the expansion of job opportunities can only be done by expanding economic activities accompanied by high labor productivity, so that the equalization of job opportunities for the population can be done. This is supported by Coal (1988) that equality of job has a very strategic position, especially for equal opportunity to participate in development.

North Sumatra is a province in the northern part of the Sumatera island. The province has the second highest population density on the island of Sumatra. The capital of north sumatera is more metropolitan than the capital of other provinces in northern Sumatra. Various things are not in accordance with the fact that the economic growth of northern Sumatra province through Gross Regional Domestic Product (PDRB). PDRB per capita of north sumatera province is still classified in low category and still under Riau, Jambi and East Kalimantan provinces.

From the above explanation above can be defined that job opportunities can affect economic growth. Based on the above exposure the authors will analyze the effect of human resources and job opportunities on economic growth in North Sumatra from 2010 to 2016 . The formulation of the problem in this study whether there is influence of human resources and job opportunities on the economic growth of north Sumatra in 2010 until 2016. Hypothesis in this study there is a significant influence between human resources and job opportunities on the economic growth of north Sumatra in 2010 until 2016.

\section{METHOD}

This quantitative research using correlation approach with multiple regression technique. This research was conducted in North Sumatra using secondary data from Central Bureau of Statistics (BPS) in the period of 2010 until 2016.

\section{A. Variable Definition}

Human resources is a collection of people who perform economic activities. This variable is measured by Human Development Index (HDI) and becomes independent variable $\left(\mathrm{X}_{1}\right)$. Job Opportunity is the ratio of the percentage of working population to the total labor force and the independent variable $\left(\mathrm{X}_{1}\right)$. Economic growth is a condition of economic change of a region measured using Gross Regional Domestic Product (PDRB) and becomes a dependent variable (Y)

\section{B. Statistical Analysis Method}

The research use multiple regression analysis method to obtain regression equation $\hat{Y}=a+b_{1} X_{1}+b_{2} X_{2}$. Then test the hypothesis,

$\mathrm{H}_{0}: \mathrm{b}_{1}=\mathrm{b}_{2}=0$

$H_{a}$ : there is at least on $b_{i}=0, i=1,2$

where,

$\mathrm{H}_{0}$ : There is no significant influence between human resources and job opportunities on the economic growth of north sumatera from 2010 to 2016

$\mathrm{H}_{\mathrm{a}}$ : There is significant influence between human resources and job opportunities on the economic growth of north sumatera from 2010 to 2016

Before test the hypothesis research test the classic asumption of regression method include, normality test, linierity test, heterocedasticity test, autocorrelation test, and multicollinierity test.

\section{RESULT}

\section{A. Research Data}

Data about HDI, percentage of job opportunities and PRDB of North Sumatera Province show at Table 1 below.

TABLE 1. Research Data

\begin{tabular}{|c|c|c|c|}
\hline Year & HDI & $\begin{array}{c}\text { Percentage of } \\
\text { Job Oppurtunities }\end{array}$ & PRDB \\
\hline 2010 & $68,87 \%$ & $67,28 \%$ & 6,52 \\
\hline 2011 & $67,34 \%$ & $68,68 \%$ & 6,66 \\
\hline 2012 & $67,74 \%$ & $69,41 \%$ & 6,45 \\
\hline 2013 & $68,36 \%$ & $70,67 \%$ & 6,07 \\
\hline 2014 & $68,87 \%$ & $67,07 \%$ & 5,23 \\
\hline 2015 & $69,51 \%$ & $67,28 \%$ & 5,1 \\
\hline 2016 & $70 \%$ & $67,76 \%$ & 5,18 \\
\hline
\end{tabular}

B. Test of Classic Asumption

\section{-. Test of Normality}

Test of normality did using software SPSS 17 . For Data HDI output SPSS 17 show in Table 2. Result from Table show Sig $=0,909>0,05$ therefore Data of HDI is normal. 
For data job opportunities output SPSS 17 show in Table 3. Result from table show $\mathrm{Sig}=0,207>0,05$ therefore data of job opportunities is normal.

TABLE 2. Test of Normality on Data HDI

\begin{tabular}{|l|r|r|r|r|r|r|}
\hline \multirow{2}{*}{} & \multicolumn{2}{|c|}{ Kolmogorov-Smirnov } & \multicolumn{3}{c|}{ Shapiro-Wilk } \\
\cline { 2 - 7 } & Statistic & \multicolumn{1}{c|}{ df } & \multicolumn{1}{c|}{ Sig. } & Statistic & df & Sig. \\
\hline HDI & 0,156 & 7 & $0,200^{*}$ & 0,971 & 7 & 0,909 \\
\hline *. This is a lower bound of the true significance. \\
a. Lilliefors Significance Correction \\
?
\end{tabular}

TABLE 3. Test of Normality on Data Job Opportunities

\begin{tabular}{|l|r|r|r|r|r|r|}
\hline & \multicolumn{3}{|c|}{ Kolmogorov-Smirnov ${ }^{\text {a }}$} & \multicolumn{3}{c|}{ Shapiro-Wilk } \\
\cline { 2 - 7 } & Statistic & \multicolumn{1}{|c|}{ df } & Sig. & Statistic & df & Sig. \\
\hline Job_Opport & 0,229 & 7 & $0,200^{*}$ & 0,876 & 7 & 0,207 \\
\hline *. This is a lower bound of the true significance. \\
\hline \\
a. Lilliefors Significance Correction \\
\hline
\end{tabular}

For data PRDB output SPSS 17 show in Table 4. Result from the table show $\mathrm{Sig}=0,078>0,05$ therefore data of PRDB is normal.

TABLE 4. Test Normality on Data PRDB

\begin{tabular}{|c|c|c|c|c|c|c|}
\hline & \multicolumn{3}{|c|}{ Kolmogorov-Smirnov ${ }^{a}$} & \multicolumn{3}{|c|}{ Shapiro-Wilk } \\
\hline & Statistic & df & Sig. & Statistic & df & Sig. \\
\hline PRDB & 0,256 & 7 & 0,182 & 0,829 & 7 & 0,078 \\
\hline
\end{tabular}

\section{- Test of Linierity}

Test of linierity did using software SPSS 17 . For data HDI and PRDB output SPSS show at Table 5 below. Result from table show Sig $=0,994>0,05$ therefore Data HDI and PRDB is linier.

TABLE 5. Test of Linierity on Data HDI and PRDB

\begin{tabular}{|c|c|c|c|c|c|c|c|}
\hline & & & $\begin{array}{l}\text { Sum of } \\
\text { Squares }\end{array}$ & df & $\begin{array}{l}\text { Mean } \\
\text { Square }\end{array}$ & $\mathbf{F}$ & Sig. \\
\hline \multirow{5}{*}{$\begin{array}{l}\text { PRDB * } \\
\text { HDI }\end{array}$} & \multirow{3}{*}{$\begin{array}{l}\text { Between } \\
\text { Groups }\end{array}$} & (Combined) & 2,067 & 5 & 0,413 & 0,497 & 0,785 \\
\hline & & Linearity & 1,956 & 1 & 1,95 & 2,35 & 0,368 \\
\hline & & $\begin{array}{l}\text { Deviation from } \\
\text { Linearity }\end{array}$ & 0,112 & 4 & 0,028 & 0,034 & 0,994 \\
\hline & \multicolumn{2}{|c|}{ Within Groups } & 0,832 & 1 & 0,832 & & \\
\hline & \multicolumn{2}{|l|}{ Total } & 2,900 & 6 & & & \\
\hline
\end{tabular}

For data job opportunities and PRDB output SPSS show at Table 6. Result from table show Sig $=0,857>$ 0,05 therefore data job opportunities and PRDB is linier.

TABLE 6. Test of Linierity Data Job Opportunities and PRDB

\begin{tabular}{|c|c|c|c|c|c|c|c|}
\hline & & & $\begin{array}{l}\text { Sum of } \\
\text { Squares }\end{array}$ & df & $\begin{array}{l}\text { Mean } \\
\text { Square }\end{array}$ & $\mathbf{F}$ & Sig. \\
\hline \multirow{5}{*}{$\begin{array}{l}\text { PRDB * } \\
\text { Job_Oppor } \\
\text { t }\end{array}$} & \multirow[b]{3}{*}{$\begin{array}{l}\text { Between } \\
\text { Groups }\end{array}$} & (Combined) & 1,891 & 5 & 0,378 & 0,375 & 0,837 \\
\hline & & Linearity & 0,670 & 1 & 0,670 & 0,664 & 0,565 \\
\hline & & $\begin{array}{l}\text { Deviation } \\
\text { from } \\
\text { Linearity }\end{array}$ & 1,222 & 4 & 0,305 & 0,303 & 0,857 \\
\hline & \multicolumn{2}{|c|}{ Within Groups } & 1,008 & 1 & 1,008 & & \\
\hline & \multicolumn{2}{|l|}{ Total } & 2,900 & 6 & & & \\
\hline
\end{tabular}

- Test of Heteroscedasticity

Test of heteroscedasticity did using software SPSS 17. For data HDI dan job opportunities output SPSS show at Table 7. Result from the table show Sig of HDI $=0,102$ $>0,05$ and $\mathrm{Sig}$ of job opportunities $=0,189>0,05$ therefore both of data independent from heterocedasticity.

TABLE 7. Test of Heteroscedasticity

\begin{tabular}{|c|c|c|c|c|c|c|}
\hline \multirow{2}{*}{\multicolumn{2}{|c|}{ Model }} & \multicolumn{2}{|c|}{$\begin{array}{c}\text { Unstandardized } \\
\text { Coefficients } \\
\end{array}$} & \multirow{3}{*}{$\begin{array}{c}\text { Standardized } \\
\text { Coefficients } \\
\text { Beta } \\
\\
\end{array}$} & \multirow{3}{*}{\begin{tabular}{c|}
$\mathbf{t}$ \\
\\
2,076 \\
\end{tabular}} & \multirow{3}{*}{$\begin{array}{l}\text { Sig. } \\
0,041 \\
\end{array}$} \\
\hline & & \multirow{2}{*}{$\begin{array}{c}\text { B } \\
46,22 \\
\end{array}$} & \multirow{2}{*}{$\begin{array}{l}\text { Std. } \\
\text { Error } \\
26,50 \\
\end{array}$} & & & \\
\hline \multirow{3}{*}{1} & (Constant) & & & & & \\
\hline & HDI & -033 & 0,020 & $-1,304$ & $-1,651$ & 0,102 \\
\hline & Job_oppurt & 0,025 & 0,019 & 1,044 & 1,323 & 0,189 \\
\hline
\end{tabular}

- Test of Autocorrelation

Test of autocorrelation did using software SPSS 17. For data HDI, job opportunities, and PRDB output show at Table 8 below.

TABLE 8. Determine Durbin-Watson index by SPSS 17

\begin{tabular}{|l|c|r|r|r|r|}
\hline Model & R & R Square & $\begin{array}{c}\text { Adjusted R } \\
\text { Square }\end{array}$ & $\begin{array}{r}\text { Std. Error of } \\
\text { the Estimate }\end{array}$ & Durbin-Watson \\
\hline 1 & $0,912^{\mathrm{a}}$ & 0,831 & 0,826 & 0,007007 & 1,906 \\
\hline
\end{tabular}

Result from table show Durbin-Watson index is 1,906. Based on seven year and two independent variable gained $d_{L}=1,6131$ and $d_{U}=1,7364$. Hence ; $d_{U}<D W<$ $\left(4-\mathrm{d}_{\mathrm{U}}\right)$ that $1,7364<1,906<2,2636$ therefore All data is independent from autocorrelation. 
- Test of Multicolinerity

Test of multicolinierity did using sofrware SPSS 17. For data HDI and job opportunities output show at table 9 below.

TABLE 9. Determine VIF by SPSS

\begin{tabular}{|l|r|r|r|r|r|}
\hline \multirow{2}{*}{ Model } & \multicolumn{1}{|c|}{$\begin{array}{c}\text { Standardized } \\
\text { Coefficients }\end{array}$} & \multirow{2}{*}{ t } & \multirow{2}{*}{ Sig. } & \multicolumn{2}{|c|}{ Collinearity Statistics } \\
\cline { 2 - 6 } & \multicolumn{1}{|c|}{ Beta } & & & Tolerance & \multicolumn{1}{c|}{ VIF } \\
\hline & & $-10,335$ & 0,000 & & \\
\hline (Constant) & 1,150 & 3,279 & 0,001 & 0,014 & 69,867 \\
\hline HDI & $-1,040$ & $-2,960$ & 0,004 & 0,014 & 78,795 \\
\hline $\begin{array}{l}\text { Job_ } \\
\text { opport }\end{array}$ & & & & & \\
\hline
\end{tabular}

Result from the table show VIF of Data HDI = 69,867 and VIF data job opportunities $=78,995$. Both data $>10$ therefore both data independent of multicolinierity.

\section{Test of Hypothesis}

Regression equation is gained based on Research Data. Equation is $\hat{\mathrm{Y}}=46,229+0,559 \mathrm{X}_{1}+0,012 \mathrm{X}_{2}$. Then test of hypothesis where;

$\mathrm{H}_{0}: \mathrm{b}_{1}=\mathrm{b}_{2}=0$

$\mathrm{H}_{\mathrm{a}}$ : there is at least on $b_{i}=0, i=1,2$

where,

$\mathrm{H}_{0}$ : There is no significant influence between human resources and job opportunities on the economic growth of north sumatera from 2010 to 2016

$\mathrm{H}_{\mathrm{a}}$ : There is significant influence between human resources and job opportunities on the economic growth of north sumatera from 2010 to 2016

Test of hypothesis did using software SPSS 17. From the output show at Table10 we get $\mathrm{Sig}=0,015<0,05$ therefore $\mathrm{H}_{0}$ was rejected and $\mathrm{H}_{\mathrm{a}}$ was accepted. Hence, there is significant influence between human resources and job opportunities on the economic growth of north sumatera province from 2010 to 2016.

TABLE 10. Test of Hypothesis of Multiple Regression

\begin{tabular}{|c|c|c|c|c|c|c|}
\hline \multirow{2}{*}{\multicolumn{2}{|c|}{ Model }} & \multicolumn{2}{|c|}{$\begin{array}{c}\text { Unstandardized } \\
\text { Coefficients } \\
\end{array}$} & \multirow{3}{*}{$\begin{array}{c}\text { Standardized } \\
\text { Coefficients } \\
\text { Beta }\end{array}$} & \multirow[t]{2}{*}{$\mathbf{t}$} & \multirow[t]{2}{*}{ Sig. } \\
\hline & & $\mathbf{B}$ & $\begin{array}{l}\text { Std. } \\
\text { Error }\end{array}$ & & & \\
\hline \multirow{3}{*}{1} & (Constant) & 46,229 & 26,506 & &, 744 &, 015 \\
\hline & HDI & ,599 &, 256 & ,809 & 2,336 & ,080 \\
\hline & Job_Opport & ,012 &, 179 &, 022 & 065 & ,952 \\
\hline
\end{tabular}

\section{CONCLUSION AND SUGGESTION}

Result of the research that there is influence of human resources and job opportunites on economic growth in north sumatera province in 2010 to 2016. Based on regression equation that $\hat{Y}=46,229+0,559 X_{1}+0,012 X_{2}$, show that $b_{1}$ $=0,559$ and $b_{2}=0,012$. Hence, human resources (HDI) give more influence on economic growth than job oppurtunities

Based on result of the research researcher suggest for goverment to enhance human resources (HDI) in order to increase north sumatera's economic growth.

\section{REFERENCES}

[1] Jhingan, M.L. "Ekonomi Pembangunan dan Perencanaan". Jakarta: PT Raja Grafinda Persada. 2004

[2] Sadono, Sukirno. "Ekonomi Pembangunan". Jakarta: Universitas Indonesia. 1995

[3] Soeroto, "Strategi Pembangunan dan Perencanaan Kesempatan Kerja". Yogyakarta: BPFE-Pers. 1986

[4] Sudarman, Ari. “Teori Ekonomi”. Jakarta: Erlangga. 1986

[5] Sunindhia, Y.W., dan Widiyanti, Ninik. "Manajemen Tenga Kerja". Jakarta: Bina Aksara. 1989.

[6] Walpole, Ronald E. "Pengantar Statistika”. Bandung: Tarsito. 1998. 